\title{
Bowing of dimensional granitic stones
}

\author{
P. Vázquez $\cdot$ S. Siegesmund $\cdot$ F. J. Alonso
}

Received: 12 August 2010/ Accepted: 16 November 2010/Published online: 3 December 2010

(C) The Author(s) 2010. This article is published with open access at Springerlink.com

\begin{abstract}
Bowing is a well-known phenomenon seen in marbles used as building veneers. This form of rock weathering occurs as a result of external factors such as temperature, humidity, the system for anchoring the marble slabs or the panel dimensions. Under the same external conditions, many factors will determine the degree of deformation including petrography, thermal properties and residual locked stresses. The usual way to solve the problem of bowed marble slabs is to replace them with other materials, such as granites, in which the deformation still exists but is less common. In this study, eight ornamental granites with different mineralogy, grain size, grain shape, porosity and fabric were tested in a laboratory to assess their susceptibility to bowing. Three slabs of granite, each cut with a different orientation, were studied under different conditions of temperature $\left(90\right.$ and $\left.120^{\circ} \mathrm{C}\right)$ and water saturation (dry and wet) to investigate the influence of these factors together with that of anisotropy. At $90^{\circ} \mathrm{C}$, only the granite with the coarsest grain size and low porosity exhibited deformation under wet conditions. At $120^{\circ} \mathrm{C}$ and wet conditions, three of the granites showed evident signs of bowing. Again, the granite with the coarsest grain size was the most deformed. It was concluded that the wide grain size distribution influences microcracking more than other expected factors, such as the quartz content of the rock. Also, mineral shape-preferred
\end{abstract}

P. Vázquez $(\bowtie) \cdot$ F. J. Alonso

Department of Geology, University of Oviedo,

Jesus Arias de Velasco s/n, 33005 Oviedo, Spain

e-mail: pvazquez@geol.uniovi.es

S. Siegesmund

Geoscience Centre, University Göttingen,

Goldschmidtstrasse 3, 37077 Göttingen, Germany orientation and porosity play an important role in the bowing of the studied granites.

Keywords Granitoids - Bowing - Texture ·

Thermal expansion

\section{Introduction}

Bowing is one of the most spectacular deterioration features seen in dimensional stones used in façades. The phenomenon is well known in marbles, having been observed in various scenarios from ancient gravestones (Grimm 1999) to modern buildings such as the Amoco building in Chicago, Oeconomicum building in Göttingen (Koch and Siegesmund 2002) or Finlandia Hall in Helsinki (Ritter 1992). A more recent summary of marble bowing is given by Siegesmund et al. (2008a), in which the latest and the most important hypotheses debated in scientific literature are presented. Siegesmund's comparative case study is based on three different public buildings, which are clad with Peccia marble, Rosa Estremoz and Carrara marble, respectively.

Marbles may show bowing after a short period of exposure due to the anisotropic behaviour of calcite crystals with thermal variations. When heated, calcite crystal expands $\left(26 \times 10^{-6} /{ }^{\circ} \mathrm{C}\right)$ parallel to the crystallographic $\mathrm{c}$-axis and contracts $\left(-6 \times 10^{-6} /{ }^{\circ} \mathrm{C}\right)$ in a direction normal to it (Kleber 1990). Historically, some researchers have attributed the bowing exclusively to the effects of repeated heating-cooling cycles (Sir Rayleigh 1934; Rosenholtz and Schmidt 1949; Ondrasina et al. 2002). Logan et al. (1993) and Logan (2004) suggested that the bowing of the marble slabs in the Amoco building was due to the anomalous expansion-contraction behaviour of calcite combined with 
the release of locked residual stresses. Scheffzük et al. (2007) performed bowing tests on Carrara marble together with measurements of lattice-preferred orientation (LPO), residual strain and thermal expansion, and concluded that the so-called locked-in stress had an important impact on the bowing of marbles.

Winkler $(1994,1996)$ explained the expansion and warping phenomena as the result of stress relief aided by hygric action, whilst Bortz et al. (1988) stated that the deformation was due to variations in moisture content. Koch and Siegesmund $(2002,2004)$ and Grelk et al. (2004) agree that a combination of these factors is necessary for bowing to occur "....repetitive heating-cooling under dry conditions leads to considerable inelastic residual strain only in the first thermal cycle. The residual strain continuously increases again if water is present, whereby the moisture content after a thermal cycle has a certain impact on the decay rate" (Koch and Siegesmund 2004).

Microstructure-based, finite element simulations were used by Weiss et al. (2002, 2003); Saylor et al. (2007) and Shushakova et al. (2010) and provided an excellent insight into the magnitude and mechanisms of thermal degradation. It is evident that grain size, shape, fabric, interlocking and crystallographic-preferred orientation are all important (see also the discussion in Zeisig et al. (2002)). In situ observation reported by Luque et al. (2010) supported the results of the modelling done by the earlier researchers above.

Bowing is not related only to marbles. Grimm (1999) and Siegesmund (2008) reported that slabs made of granite, conglomerate or limestone may also show bowing. Winkler (1996) referred to warping in granite cemetery slabs, which had been installed only 20 years previously. Continuous exposure to almost $100 \%$ relative humidity (RH) and higher temperatures inside the tomb cavity had expanded the stone slabs more on the inside than on the outside, causing bowing. Siegesmund et al. (2008b) studied the bowing observed at the Maxi market in Ljubljana (Slovenia) built with Cezlak grandiorite (Fig. 1) and concluded that different volumetric expansions of the rock-forming minerals may have led to the creation of both locked-in and thermal stresses in the panels, which in turn may have caused the bowing. Generally, in cases of marble bowing, the industrial solution is to replace the deteriorated panels with granite slabs; however, the research above suggests that prior to doing so the granites themselves should also be investigated with respect to their thermal expansion behaviour.

In summary, there are numerous factors that influence marble bowing despite its simple mineralogical composition. Moreover, even if only a single factor is considered, the conclusions may be contradictory depending on which materials are compared. Therefore, to evaluate the

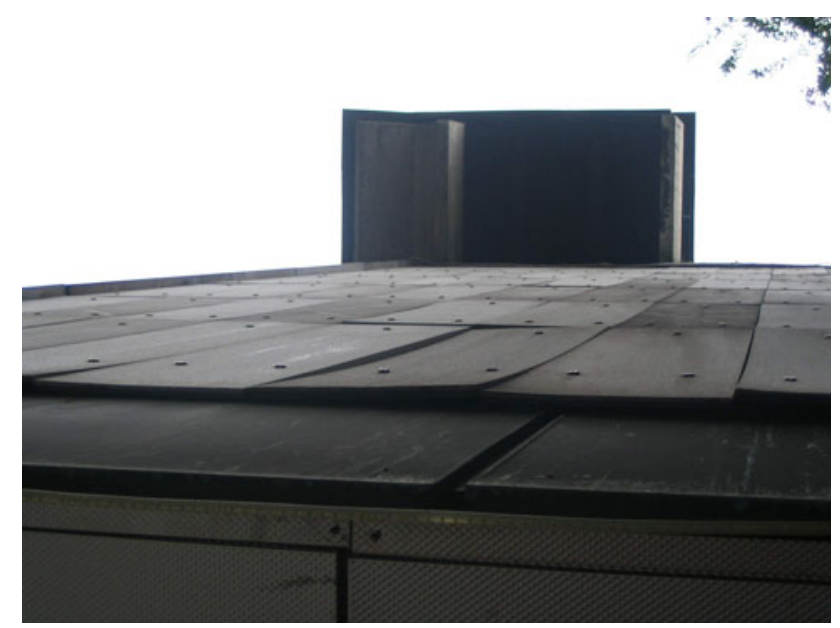

Fig. 1 Cezlak granodiotite showing bowing

deformation in heterogeneous materials such as granites, the number of variables to be taken into account will be higher.

The main aim of this study was to assess the bowing potential of various granite types with respect to their mineralogical composition and rock fabric. For that purpose, ageing tests were carried out in a laboratory under different conditions of moisture and temperature. Investigations from buildings suggest that laboratory tests can be used to simulate the decay observed in natural environments (see summary in Siegesmund 2008). From the results obtained, the influence of temperature and moisture variation on granite deformation was analysed. The objectives were to know which of the main petrographic characteristics play a key role in bowing and whether or not the mechanism of marble deformation also applies to granites.

\section{Materials}

Eight granitoids used internationally as dimensional stones were investigated. All of them differed in their mineralogical composition, grain size, rock fabric, porosity and weathering degree. Their commercial names are Albero (A), Grissal (G), Gris Alba (GA), Negro Galicia (NG), Rosavel (R) and Rosa Porriño (RP), all from Spain; Golden Ski (GS) from Portugal; and the ortogneiss Multicolor Red (RM) from India (Fig. 2).

The petrographic characteristics of the eight granitoids are given in Table 1. Mineral proportion and grain size were studied using optical polarisation microscopy (MOP) and digital image processing (DIP). Grain boundary shapes and orientation, and the systems of microcracking, were also assessed using MOP. Basic physical properties, which may influence the bowing, were measured. Density and 

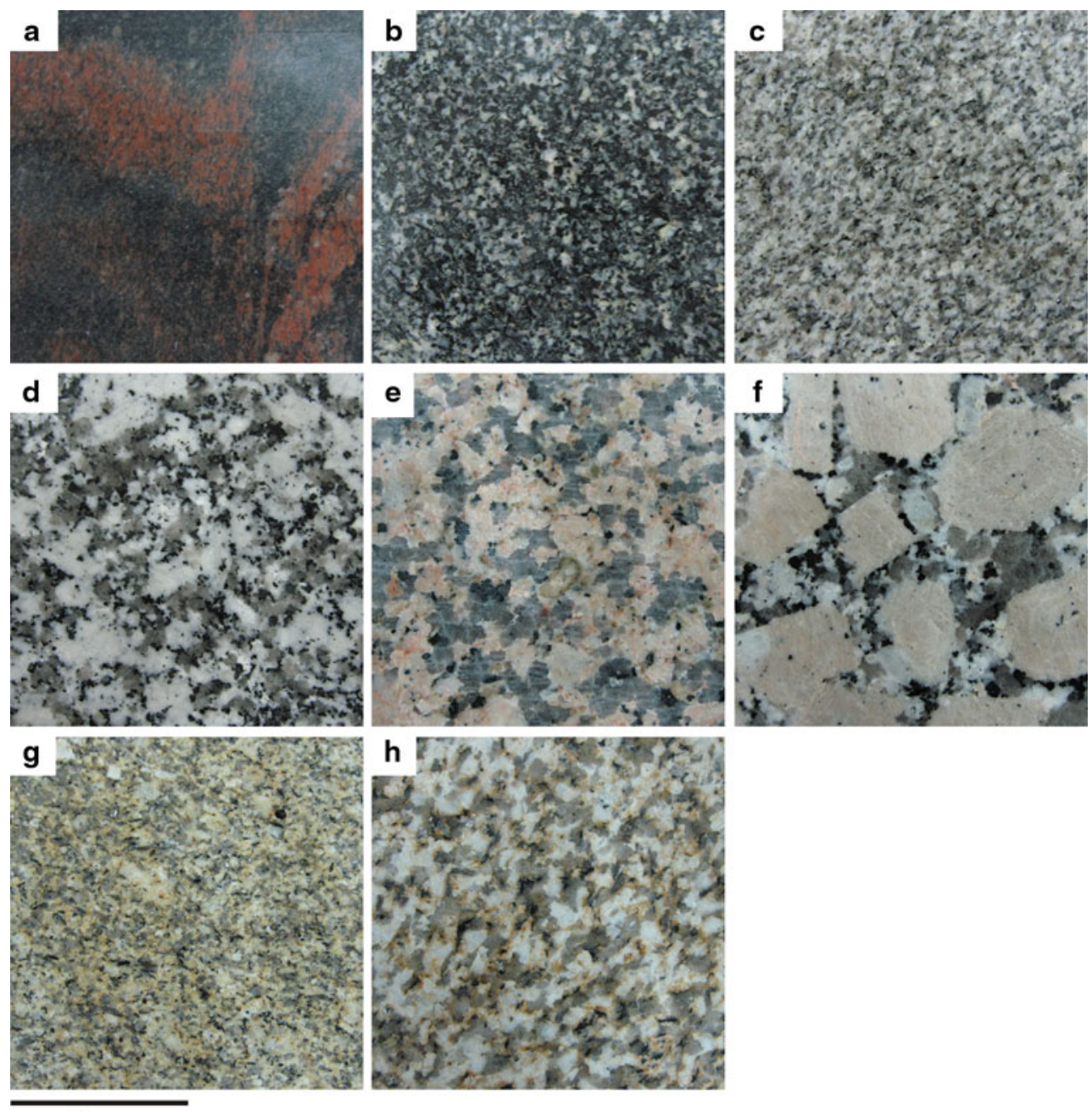

$5 \mathrm{~cm}$

Fig. 2 Macrophotos of the selected granites. a Rojo Multicolor, b Negro Galicia, c Gris Alba, d Grissal, e Rosa Porriño, f Rosavel, g Golden Ski, h Albero

Table 1 Main characteristics of the selected granitoids

\begin{tabular}{|c|c|c|c|c|c|c|c|c|c|c|}
\hline \multirow[t]{2}{*}{ Trade name } & \multirow[t]{2}{*}{ Petrographical classification } & \multicolumn{4}{|c|}{ Modal content in vol. (\%) } & \multicolumn{5}{|c|}{ Grain size $(\mathrm{mm})$} \\
\hline & & Q & $\mathrm{KF}$ & $\mathrm{P}$ & M & Q & $\mathrm{KF}$ & $\mathrm{P}$ & M & Avrg. \\
\hline Rojo Multicolor (RM) & Ortogneiss & 10 & 40 & & 50 & $<1$ & $<1$ & $<1$ & $<1$ & $<1$ \\
\hline Negro Galicia $(\mathrm{NG})^{\mathrm{a}}$ & Tonalite & 18 & & 37 & 24 & 5 & & 4 & 2.5 & 3 \\
\hline Gris Alba (GA) & Monzogranite & 23 & 37 & 23 & 17 & 5 & 5 & 4 & 2 & 4 \\
\hline Grissal (G) & Monzogranite & 25 & 35 & 32 & 8 & 8 & 18 & 9 & 2 & 11 \\
\hline Rosa Porriño (RP) & Syenogranite & 29 & 49 & 13 & 9 & 10 & 17 & 7 & 3 & 12 \\
\hline Rosavel (R) & Quartzsienite & 12 & 60 & 20 & 8 & 10 & 33 & 14 & 3 & 25 \\
\hline Golden Ski (GS) & Monzogranite & 43 & 27 & 18 & 12 & 4 & 4 & 4 & 2 & 4 \\
\hline Albero (A) & Granodiorite & 35 & 10 & 30 & 25 & 5 & 5 & 6 & 4 & 5 \\
\hline
\end{tabular}

Trade name, Streckeisen classification (1976), mineral percentage and grain size

$Q$ quartz, $K F$ alkali feldspar, $P$ plagioclase, $M$ mica

${ }^{a} \mathrm{NG}$ has amphiboles and pyroxenes completing the percentage with $2.5 \mathrm{~cm}$ of average size 
Table 2 Basic physical properties of the selected granitoids

\begin{tabular}{llllllll}
\hline Trade name & $\begin{array}{l}\Phi \\
(\%)\end{array}$ & $\begin{array}{l}\rho(\mathrm{kg} / \\
\left.\mathrm{m}^{3}\right)\end{array}$ & \multicolumn{5}{l}{$\alpha\left(10^{-06} /{ }^{\circ} \mathrm{C}\right)$} \\
\cline { 5 - 8 } & & & & $Y$ & $Z$ & Average \\
\hline $\begin{array}{l}\text { Rojo Multicolor } \\
\quad(\mathrm{RM})\end{array}$ & 0.6 & 2,640 & 6.74 & 6.70 & 8.15 & 7.30 \\
Negro Galicia (NG) & 0.5 & 2,830 & 8.37 & 8.60 & 8.75 & 8.53 \\
Gris Alba (GA) & 1.2 & 2,630 & 7.89 & 7.80 & 7.36 & 7.76 \\
Grissal (G) & 0.7 & 2,640 & 9.54 & 10.10 & 8.63 & 9.83 \\
Rosa Porriño (RP) & 1.1 & 2,600 & 7.94 & 7.25 & 6.52 & 7.59 \\
Rosavel (R) & 0.9 & 2,600 & 8.98 & 8.87 & 6.98 & 8.59 \\
Golden Ski (GS) & 2.4 & 2,560 & 9.89 & 9.02 & 9.12 & 9.70 \\
Albero (A) & 5.3 & 2,505 & 9.36 & 9.81 & 10.30 & 9.91 \\
\hline
\end{tabular}

Trade name, open porosity $(\Phi)$, apparent density $(\rho)$ and linear thermal expansion $(\alpha)$

open porosity were obtained following the UNE-EN 1936 standard. Linear thermal expansion coefficients $(\alpha)$ were determined in three normal directions ( $X$ and $Y$, parallel to the foliation plane, and $Z$ normal to it) using a dilatometer (Strohmeyer 2003) (Table 2).

With regard to the granitoids' mineralogy (see Table 1), RM (Fig. 2a) is an orthogenesis with alkali feldspar quartzsyenitic composition. Rosavel (Fig. 2f) is a porphyritic quartz syenite with lower quartz content and the highest proportion of perthitic potassium feldspar phenocrysts amongst all the studied stones. RP (Fig. 2e) is a syenogranite also with a higher proportion of alkali feldspar than plagioclase and with a high quartz content. GA, G and GS (Fig. 2c, d and g, respectively) are monzogranites with similar proportions of alkali and plagioclase feldspars. Amongst them, GS has the highest quartz and the lowest feldspar content. GA is a two-mica monzogranite with a muscovite:biotite proportion approximately of 2:1. Albero (Fig. 2h) is a two-mica granodiorite with a high content of mica, quartz and plagioclase. NG (Fig. 2b) is a tonalite with about $20 \%$ of amphiboles and pyroxenes.

The orientation of the $X Y Z$ axes are as follows: $Z$ is the direction normal to the foliation plane defined by the main crack system and mica plane orientation in the quarry, which corresponds to the saw plane. $X$ and $Y$ were not oriented with respect to the quarry, so when the granite had a directional characteristic by which it could be oriented (for example, a mineral or crack alignment), the orientation was designated to be the direction of the $X$ axis. In cases where no visible orientations could be discerned, the direction of $X$ was established at random. GA, GS and Albero exhibit mineral shape orientation in the $X Y$ plane, parallel or slightly diagonal to the $X$ axis (see Fig. 2c, g, h, respectively). NG presents the mica and Rosavel the Kfeldspars oriented parallel to the $Y$ axis. RP shows the main crack system parallel to the $X$ axis and the secondary one parallel to the $Z$ axis. In Grissal, without any macroscopic rock fabrics, the $X$ and $Y$ axes were selected randomly. In $\mathrm{RM}$, the $X Y$ plane shows folded foliation, whilst the other two planes exhibit mineral orientation parallel to the axial planes of the folds (Fig. 4b).

RM (Fig. 2a) has a metamorphic fabric. The plane that corresponds to the industrial sawing plane shows folded foliation. This rock has the smallest grain size amongst the granites studied, although isolated alkali feldspar phenocrysts, commonly of millimetric size, can be found. RM shows irregular grain interlocking due to metamorphic processes. NG, GA and GS (Fig. 2b, c, g, respectively) are fine grained granites with evident mica orientation. They differ in mineralogy and porosity. GA and NG have hypidiomorphic to allotriomorphic minerals with irregular boundaries in quartz, whilst most of the minerals in GS present idiomorphic shapes. Albero (Fig. 2h) is also fine grained, but coarser than NG, GA and GS, and with elongated allotriomorphic minerals following the foliation. The coarse-grained Grissal (Fig. 2d) and RP (Fig. 2e) rocks differ in their alkali feldspar type. No macroscopic foliation can be observed in Grissal. The fundamental crack system of RP can be observed in the quartz grains with two crack orientations, one that corresponds to the foliation plane and another one normal to it. Rosavel (Fig. 2f) is a porphyritic granite with alkali feldspar phenocrysts up to $60 \mathrm{~mm}$ in length. Feldspars in Grissal, RP and Rosavel are idiomorphic with straight grain boundaries, whilst the quartz in these rocks show straight and interlobate grain boundaries. The shorter a-axis of K-feldspars in Rosavel is observed almost normal to the foliation plane (Vázquez 2010).

Most of the stones have low open porosity, with values between 0.5 and $1 \%$. All of them are 'quarry fresh', and the most common weathering patterns are microcracks in quartz and sericitization in plagioclase. Albero and GS show a notable initial weathering with the presence of clays and open transgranular cracks, and consequently the highest porosity amongst the studied granites.

The most porous granites (Albero and GS), together with Grissal, show the highest average thermal expansion (Table 2), whilst GA, RP and RM show the lowest. Regarding anisotropy, GA, Grissal, RP and Rosavel exhibit the lowest thermal expansion perpendicular to the foliation plane $(Z)$, and RM exhibits the highest.

\section{Bowing test}

The bowing tests were carried out according to the Nordtest Method NT BUILD 499 (2002). Three slabs of each granite were placed in a bed of grit at a distance of $50 \mathrm{~mm}$ to the heating system (Fig. 3). The slabs were sawed in 


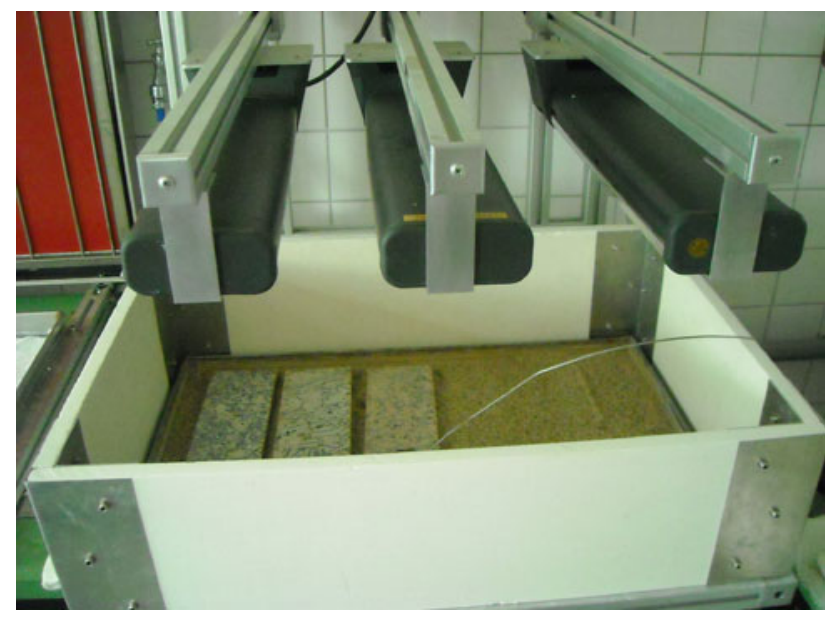

Fig. 3 Experiment set up with some of the slabs

different directions in relation to the rock fabrics to characterise the anisotropic behaviour of the rock materials (Fig. 4). In this study, the $X Y$ plane coincided in all the granites (except for RM) with the foliation plane, which related also to the preferred sawing direction in the quarries. The slab dimensions were $40 \times 10 \times 1.5 \mathrm{~cm}$. In recent years, $3 \mathrm{~cm}$ has been the typical thickness for a façade panel in industrial practice, however, the current trends in building stone manufacturing are to produce thinner slabs. In addition, Grelk et al. (2004) and Siegesmund et al. (2008b) observed a higher degree of bowing in thinner slabs.

In this study, the test performed included 36 heatingcooling cycles. To assess the influence of moisture and temperature on the deformation of the different granites, the test was divided into four stages of nine repetitive cycles. Heating took $6 \mathrm{~h}$ followed by $18 \mathrm{~h}$ of cooling at room temperature:
- Stage 1: heating up to $90^{\circ} \mathrm{C}$ in dry conditions;

- Stage 2: heating up to $90^{\circ} \mathrm{C}$ in wet conditions;

- Stage 3: heating up to $120^{\circ} \mathrm{C}$ in dry conditions;

- Stage 4: heating up to $120^{\circ} \mathrm{C}$ in wet conditions.

The wet conditions were obtained by adding water to the grit bed until it reached about $5 \mathrm{~mm}$ from the bottom of the slabs; this gave a wet bottom surface and a dry upper surface (Siegesmund et al. 2008b).

The bowing was measured after each cycle with a measurement bridge (accuracy $\pm 1 \mu \mathrm{m} / 35 \mathrm{~cm}$ ). The zero position was calibrated using a core of silica glass with coplanar surfaces. The deformation was detected in $\mathrm{mm} / \mathrm{m}$, calculated according to the circle equation of Koch and Siegesmund (2004), where positive values indicate convex bowing and negative values indicate concave bowing (Fig. 5).

\section{Results}

The results of the bowing test are given in Fig. 6, with the outcome of each third cycle shown.

During the first stage, with heating up to $90^{\circ} \mathrm{C}$ and dry conditions, the eight granites hardly exhibited any deformation. Grissal and the porous granites, Albero and GS, showed the greatest concave bowing, between 0.3 and $0.35 \mathrm{~mm} / \mathrm{m}$. Amongst all the samples, only GS presented convex deformation (in the $Z Y$ slab) with maximum values in the second cycle $(0.5 \mathrm{~mm} / \mathrm{m})$. In the second stage, with the same temperature but adding water to the bottom surface, the trend in deformation varied. Four of the granites, GA, NG, Albero and RM, became concave in the first cycle of the stage, but thereafter, the general deformation of all the stones was to convex shapes. Only Rosavel displayed remarkable behaviour, by reaching values up to $0.7 \mathrm{~mm} / \mathrm{m}$,
Fig. 4 Orientation of the slabs. $X Y$ corresponds to the foliation plane. a Grissal. b Rojo Multicolor with a different foliation plane than the industrial one. The slabs are named as the plane in which they are included
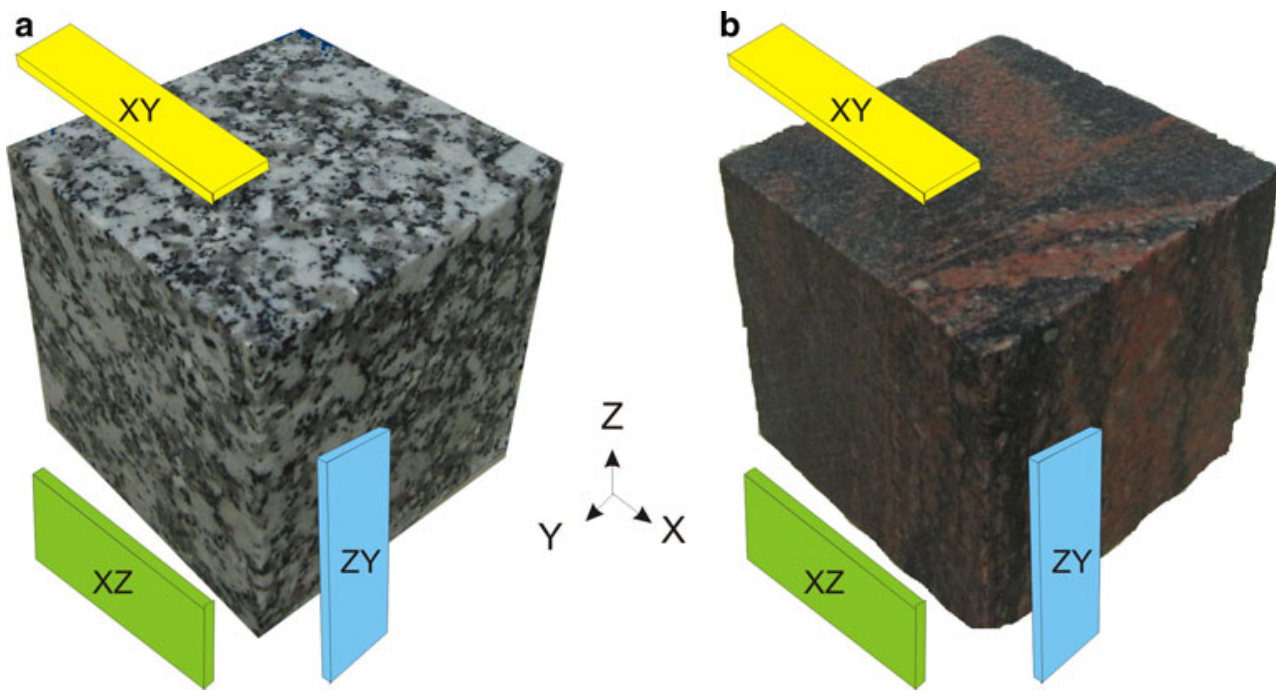


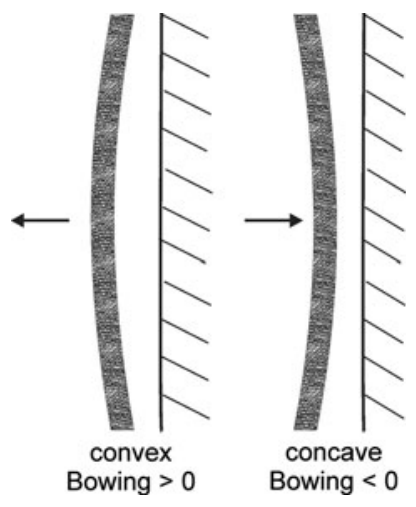

Fig. 5 Convex and concave deformation in relation with bowing values and placement in the building which was significantly higher than the values measured in the rest of the stones. In the third stage, with the increase of temperature and dry conditions, almost all the samples showed concave or no further deformation. Only GS and Albero in the $Z Y$ slab continued with convex bowing, although the values of deformation were very low at 0.13 and $0.18 \mathrm{~mm} / \mathrm{m}$, respectively. In the fourth stage, all the slabs bent in a convex direction and the deformation values for most of them were comparable to those shown throughout the earlier stages. However, three of the granites exhibited considerable bowing. Grissal and RP showed similar bowing in all the slabs, up to 1 and $0.7 \mathrm{~mm} / \mathrm{m}$, respectively. Rosavel was the granite that experienced the highest, and clearly anisotropic, bowing; The $Z Y$ slab
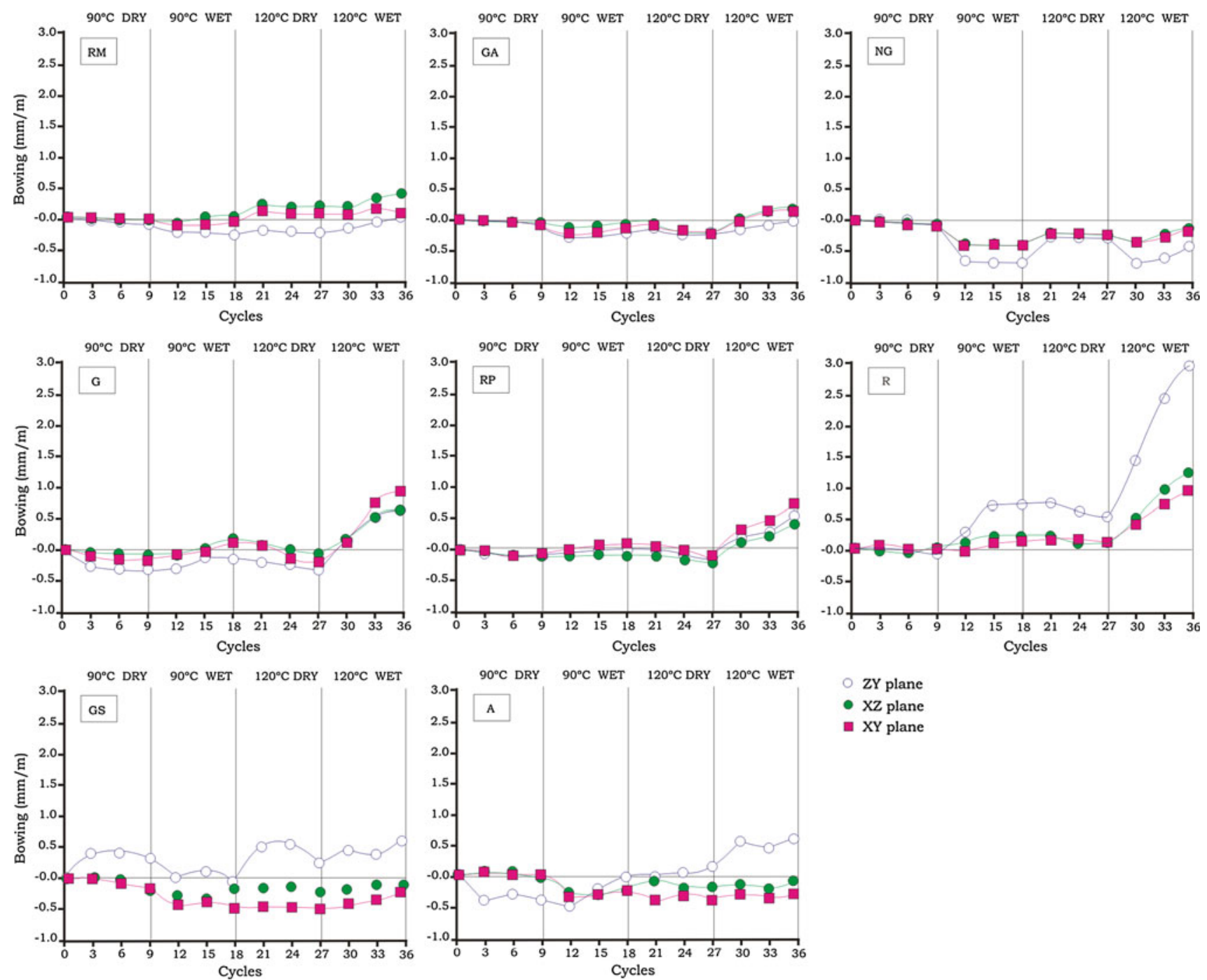

$$
\begin{aligned}
& \text { ZY plane } \\
& \mathrm{XZ} \text { plane } \\
& \mathrm{XY} \text { plane }
\end{aligned}
$$

Fig. 6 Bowing of the eight ornamental granites along the four different stages, with nine cycles in each stage. Each third cycle is drawn. The three different orientations are shown. The abrupt change in some of the granites in the last stage with the most extreme conditions evidence the bowing potential of these stones 
presented deformation of up to $3 \mathrm{~mm} / \mathrm{m}$ at the end of the test, whilst the other two directions had final values of about $1 \mathrm{~mm} / \mathrm{m}$. At the end of the test, in Rosavel clay minerals were observed filling cracks in the upper face.

In summary, after all four stages of the test, three groups can be distinguished:

1. Granites that hardly showed any bowing: RM, NG and GA. These three granites have mineral shape-preferred orientation, small grain size and low porosity. They suffered bowing, but it was not comparable to the rest of the granites.

2. Granites that experienced bowing only in wet conditions and more evidently with high temperature: G, RP and $\mathrm{R}$. These granites have the coarsest grain size of all the granites, combined with low porosity. They showed a pronounced change in the last stage of the test, deforming to convex shapes. In this group, only Rosavel exhibits mineral shape-preferred orientation (feldspars).

3. Granites that showed high absolute deformation, but no progressive tendency: Albero and GS. Both are weathered granites with mineral shape-preferred orientation, high porosity and the presence of clays. The graphs below (Fig. 6) show that the granites both followed a deformation trend that did not change with temperature or between dry and wet conditions.

\section{Discussion}

The bowing of stones is considered to be produced as a result of anomalous mineral expansion in response to temperature and moisture variations. Thermal expansion is a more complex process in granitoids than it is in marbles due to the presence of different mineral phases and fabrics. During heating and cooling, temperature differentials between the different minerals, combined with differing thermal mineral expansion values, may initiate cracks or cause existing cracks to grow or propagate, as was suggested by Siegesmund et al. (2008b) and also observed in microscopic studies by Mauko et al. (2006).

Within the major rock-forming minerals of the investigated granitoids (see Table 1), the expansion in volume of quartz and mica is about four times higher than that of feldspars with the following values [in $10^{-6} / \mathrm{K}$ ]: 37.0 quartz, 35.4 muscovite, 9.7-15.6 K-feldspar, 8.9-15.4 plagioclase and 6.6 albite (data from Strohmeyer 2003 and Fei 1995). This contrast may cause internal stresses to build up during heating, leading to the development of microcracks in quartz boundaries and the opening of cleavage planes in mica, as Siegesmund et al. (2008b) have discussed. Volume expansion is further enhanced when minerals with anisotropic thermal expansion show a crystallographic orientation. This is highly relevant for quartz and mica, which, in addition to demonstrating the highest linear thermal expansion of all the minerals in the investigated granitoids, also show the most anisotropic values, with coefficients in quartz of $\alpha=7.7 \times 10^{-6} / \mathrm{K}$ parallel to the c-axis and $13.3 \times 10^{-6} / \mathrm{K}$ perpendicular to it, whilst in mica these values are $17.3 \times 10^{-6} / \mathrm{K}$ and $9.65 \times 10^{-6 /} \mathrm{K}$, respectively (Siegesmund et al. 2008b). For the purpose of comparison, Devore (1969) indicated that for increments in temperature up to about $100^{\circ} \mathrm{C}$, the highest alkali feldspar expansion (a-axis) is similar to the smallest quartz expansion (parallel to the c-axis). It seems likely, therefore, that granites with high quartz and mica content will show high thermal expansion (Castro de Lima and Paraguassú 2004). In agreement with this, Albero and GS, which have the highest quartz and mica content of the eight test materials, did display the highest thermal expansion. However, two of the test stones did not conform with this theory; Rosavel displayed a high thermal expansion coefficient, yet it contains the lowest quartz content, and RP displayed one of the lowest thermal expansion coefficients despite having a high quartz content (see Table 1, 2).

The determination of the linear expansion coefficient in three directions demonstrated anisotropic behaviours in most of the granites (see Table 2). RM, GA and RP had the lowest thermal expansion. GA, which showed mica orientation, is considered to be thermally isotropic (anisotropy index $A=0.07$ with $\left.A \alpha=\left(\alpha_{\max }-\alpha_{\min }\right) / \alpha_{\max }\right)$. RM and RP were significantly anisotropic (both with $A=0.18$ ). RM shows mineral shape-preferred orientation parallel to the $Z$ axis (Fig. 4b), and consequently had the highest expansion in this direction of all the granites studied. In contrast, RP exhibited the lowest expansion in the $Z$ direction, which can be explained by the presence of oriented inter- and intra-granular cracks perpendicular to $Z$, which may have minimised the expansion. Amongst them, only RP, the granite with the coarsest grain size and the highest quartz content, showed clear bowing, although with slightly higher values in the $Z$ direction $\left(A_{\text {bowing }}=0.13\right.$ where $\left.A=\left(A_{\text {bowing max }}-A_{\text {bowing } \min }\right) / A_{\text {bowing } \max }\right)$ (Fig. 6). NG and Rosavel had thermal expansion values that were intermediate amongst the granites studied. They have in common, a low quartz content (18 and 12\%, respectively) and mineral shape-preferred orientation. NG is a fine grainsized tonalite with mica orientation parallel to the foliation plane; however, its thermal expansion is isotropic $(A \alpha=0.04)$ and no bowing was observed. Rosavel presents alkali feldspar phenocrysts parallel to the foliation plane, and consequently had the lowest expansion and bowing in the $Z$ direction $\left(A \alpha=0.22\right.$ and $\left.A_{\text {bowing }}=0.61\right)$. Figure 7 shows that Rosavel's $X Y$ plane slab, parallel to the foliation, barely presents any mineral shape-preferred 


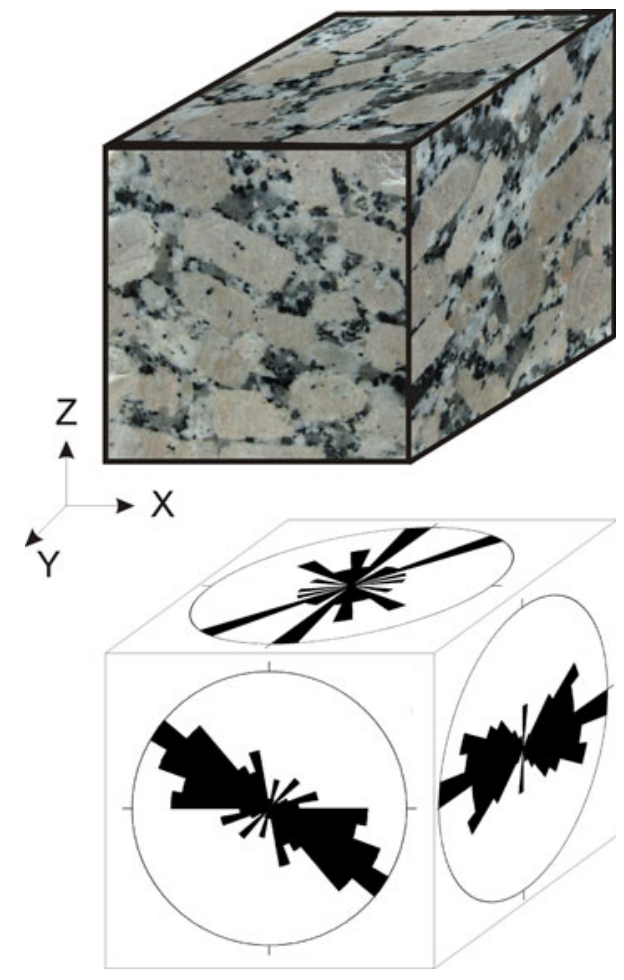

Fig. 7 K-feldspar orientation in $\mathrm{R}$ granite. $X Z$ and $Z Y$ planes show the most quantity of oriented crystals with 92 and 65 measurements, respectively. In the $X Y$ slab, only 18 oriented $\mathrm{K}$-feldspar were found. The slab with the greatest bowing followed the YZ plane and showed $\mathrm{K}$-feldspar parallel to the $Y$ axis

orientation. The slab with the greatest bowing followed the $Y Z$ plane, where $\mathrm{K}$-feldspar long axis were parallel to the short side of the panel (Y). Albero, GS and Grissal (G) had high values of linear thermal expansion coefficient and all of them showed evident deformation, although only Grissal exhibited a clear bowing (Fig. 6). Albero and GS have the highest content of all the granites studied in both quartz and mica, and their thermal expansion values are slightly anisotropic (both with $A \alpha=0.09$ and $A_{\text {bowing }}=0.50$ higher in the $X$ direction). Grissal, which does not exhibit any visible orientation, has anisotropic thermal expansion $(A \alpha=0.15)$ with the lowest values in the $Z$ direction; moreover, its bowing was a bit higher in that direction $\left(A_{\text {bowing }}=0.22\right)$ (Fig. 4a). It seems that most of the slabs in which the thickness corresponds to the direction with the lowest thermal expansion coefficients experience more deformation than slabs in which this is not the case. Therefore, to explain the bowing mineral, expansion alone must not be taken into account. The three granitoids that showed the highest bowing can be grouped according to their different values of thermal expansion (low, intermediate and high).

Other parameters that influence marble bowing, and that apply to granites also, are grain size, differences in grain size distribution and grain boundaries. Gómez-Heras et al. (2006) affirm that "...crystal size is shown to be a major control on surface temperature differences between minerals". He also attributed the generated stresses to the fact that "...stones with large differences in mineral size might be expected to experience magnified near surface stresses due to thermal expansion differences". Siegesmund et al.'s research (2008b) supported this theory when it obtained higher bowing in coarser grain-sized granite with larger phenocrysts. In this study, only the three granites with the coarsest grain size and also with straight grain boundaries ( $\mathrm{G}, \mathrm{RP}$ and $\mathrm{R}$ ) exhibited bowing when temperature and moisture acted together. Amongst them, Rosavel, with the coarsest grain size and large differences between the size of the alkali feldspars and the rest of the minerals, showed the highest bowing of all the three slabs, reaching up to $3 \mathrm{~mm} /$ $\mathrm{m}$ during the test (Fig. 6).

Bowing is influenced by external factors such as temperature and moisture. When the selected granitic stones were exposed to temperature increases up to 90 and $120^{\circ} \mathrm{C}$ in dry conditions, deformation was hardly evident (Fig. 6). The most common deformation was concave bowing (Fig. 5), probably due to the fact that the upper surface was exposed to a higher and more extreme temperature variation than the bottom one, and consequently a higher quartz contraction during cooling (Winkler 1996). In most of the cases when water is added, the trend turned into convex deformation. The mineral dilation in contact with water is strong, so the bottom surface suffers more contraction than the upper one. Malaga et al. (2008) indicated that "...crack propagation in wet rocks is more suitable because it takes more energy to replace a solid-solid contact with a solidair contact than to replace it with a solid-water contact". Only three granites did not show this trend: Albero, GS and NG. During the test, Albero and GS, which have the highest porosity amongst the stones, were water saturated in minutes due to capillary uptake, which means that the differences between the two faces were not as extreme as in the rest of the granites. NG showed a strong change to more concave shapes in the first cycles when the water was added and constant values during the rest of the wet cycles.

Other factors may also influence granite deformation; for example, residual stresses, slab thickness and albedo. Residual stresses, caused by thermal stresses amongst minerals during the uplift and cooling of the granitic pluton (Vollbrecht et al. 1991), are thought to play an important role later in microcracking during heating and cooling cycles (Siegesmund et al. 2008b). With thinner slabs, there is likely to be a higher degree of bowing although this variable was not specifically tested within the scope of this study. Gómez-Heras et al. (2006) and Hall et al. (2005) called attention to the influence of mineral albedo. As Hall (2010) pointed out, light transmissive minerals change the 
thermal response in the outer millimetres of the rock, creating thermal stresses when in contact with opaque ones. In laboratory conditions, the temperature reached by every mineral depends only on the thermal properties and interrelation with the surrounding minerals. However, when exposed outdoors, minerals with lower albedo heat up more than the lighter ones due to insolation. This enhances the stresses amongst minerals in non-laboratory conditions.

Suzuki et al. (1995) demonstrated that physical and chemical weathering both contribute to crack growth. They showed this by studying changes in granite properties after long-term immersion in hot water at $90^{\circ} \mathrm{C}$. They observed the formation of clays on the surface of the plagioclase and around microcracks after long periods of water immersion. At the end of the test in this study, Rosavel, which had the greatest bowing, exhibited clays that filled microcracks on the external slab face, i.e. the side which was not in contact with water, despite the fact that no clays were observed in the initial stone. The formation of clays, or the migration of existing ones towards the upper surface, may also produce higher stresses than those existing on the bottom surface and thus may contribute to convex deformation. The duration of the test in this study was lower than that of the test carried out by Suzuki et al. (1995). However, the water temperature in both tests was over $100^{\circ} \mathrm{C}$, which means that both studies tested the effects of liquid water and also water vapour. The presence of water in two different states may produce a different chemical environment, which may consequently create the right conditions for the occurrence of reactions that may generate clays. Microcracks increase when there are variations in temperature, which helps the clays to rise to the surface of the rock and to produce pressure on the crack walls.

\section{Conclusions}

This study of the bowing potential of ornamental granites resulted in the following conclusions:

- Granites may show bowing with values comparable to marbles when temperature and moisture act together.

- Usually, slabs that have the lowest thermal expansion coefficients normal to the slab plane tend to suffer the highest deformation.

- Porosity is one of the features that most affects deformation. Slabs with high porosity showed deformation, but not progressive bowing. This may be attributed to low differences in temperature and humidity between slab faces due to the fast water capillary uptake.

- Mineralogy also influences bowing, but is not the most important factor. For any given material, its mineral proportion, size distribution of different mineral phases and the above-mentioned porosity and thermal expansion values must be taken into account altogether.

- In this study, the key factor that determined the degree of bowing was the coarse grain size, whilst the anisotropy of the deformation was defined by the mineral shape-preferred orientation. However, both factors must be considered with care. Granites are heterogeneous materials and it is difficult to extrapolate their behaviour accurately even with several similarities between materials.

Acknowledgments We would like to thank the Ministry of Science and Innovation for their support of project MAT2004-06804-C02-01, and the FICYT for their support of project IB-09-080. Our thanks are also extended to Dr. Axel Vollbrecht for his advice and to Manuela Morales for her help during the laboratory work.

Open Access This article is distributed under the terms of the Creative Commons Attribution Noncommercial License which permits any noncommercial use, distribution, and reproduction in any medium, provided the original author(s) and source are credited.

\section{References}

Bortz SA, Erlin B, Monk CB (1988) Some field problem with thin veneer building stones. In: New stone technology, design and construction for exterior wall systems, Vol 996. ASTM, USA, pp 11-31

Castro de Lima JJ, Paraguassú AB (2004) Linear thermal expansion of granitic rocks: influence of apparent porosity, grain size and quartz content. Bull Eng Geol Environ 63:215-220

Devore GW (1969) Differential thermal contractions and compressibilities as a cause for mineral fracturing and annealing. Contr Geol 8:21-36

Fei Y (1995) Thermal expansion. In: Ahrens TJ (ed) Mineral physics and crystallography - a handbook of physical constants 2 . American Geophysical Union, Washington, p 354

Gómez-Heras M, Smith BJ, Fort R (2006) Surface temperature differences between minerals in crystalline rocks: Implications for granular disaggregation of granites through thermal fatigue. Geomorphology 78:236-249

Grelk B, Goltermann P, Schouenborg B, Koch A, Alnæs L (2004) The laboratory testing of potential bowing and expansion of marble. In: Prikryl R (ed) Dimension stone. Taylor \& Francis, London, pp 253-259

Grimm WD (1999) Observations and reflections on the deformation of marble objects caused by structural breaking up. Zeitschrift der Deutschen Geologischen Gesellschaft 150(2):195-235

Hall K (2010) Natural building stone composed of light-transmissive minerals: impacts on thermal gradients, weathering and microbial colonization. A preliminary study, tentative interpretations, and future directions. Environ Earth Sci 47:866-869. doi: 10.1007/s12665-010-0522-6

Hall K, Lindgren BS, Jackson P (2005) Rock Albedo and monitoring of thermal conditions in respect of weathering: some expected and some unexpected results. Earth Surf Process Landforms 30:801-811

Kleber W (1990) Einführung in die Kristallographie. VEB Verlag Technik, Berlin 
Koch A, Siegesmund S (2002) Bowing of marble panels: on-site damage analysis from the oeconomicum building at Göttingen (Germany). In: Siegesmund S, Weiss T, Vollbrecht A (eds) Natural stone, weathering phenomena, conservation strategies and case studies. Geol Soc London Spec Pub 205:299-314

Koch A, Siegesmund S (2004) The combined effect of moisture and temperature on the anomalous expansion behaviour of marble. Environ Geol 46:350-363

Logan JM (2004) Laboratory and case studies of thermal cycling and stored strain on the stability of selected marbles. Environ Geol 46:456-467

Logan JM, Hadedt M, Lehnert D, Denton M (1993) A case study of the properties of marble as building veneer. Int J Rock Mech Min Sci Geomech Abstr 30:1531-1537

Luque A, Ruiz-Agudo E, Cultrone G, Sebastian E, Siegesmund S (2010) Direct observation of microcrack development in marble caused by thermal weathering. Environ Earth Sci doi: 10.1007/s12665-010-0624-1

Malaga K, Schouenborg B, Grelk B (2008) Bowing and expansion of natural stone panels. Mat Const 58(289-290):97-112

Mauko A, Mirtic B, Mladenovic A, Grelk B (2006) Deterioration of the granodiorite façade-case sample Maximarket, Ljubljana. RMZ-Mat Geoenviron 53(1):23-37

NT BUILD 499 (2002). Cladding panels: test for bowing

Ondrasina J, Kirchner D, Siegesmund S (2002) Freeze-thaw cycles and their influence in marble deterioration: a long term experiment. In: Siegesmund S, Weiss T, Vollbrecht A (eds) Natural stone, weathering phenomena, conservation strategies and case studies. Geol Soc London Spec Pub 205: 9-18

Rayleigh A (1934) The bending of marble. Proc R Soc London 266:79

Ritter H (1992) Die Marmorplatten sind falsch dimensioniert. Stein $\mathrm{H} 1: 18-19$

Rosenholtz JL, Schmidt DT (1949) Linear thermal expansion of calcite, var., Iceland sparite and Yule marble. Am Miner 34:846-854

Saylor DM, Fuller ER, Weiss T (2007) Thermal-elastic response of marble polycrystals: influence of grain orientation configuration. Intl J Mat Res (formerly Z. Metallkd.) 98(12):1-8

Scheffzük C, Siegesmund S, Nikolayew D, Hoffmann A (2007) Spatial and orientation dependence of internal strain in marbles. In: Prikryl R, Smith BJ (eds) Building stone decay: from diagnosis to conservation. Geol Soc London Spec Pub 271: 237-249

Shushakova V, Fuller Jr ER, Siegesmund S (2010) Influence of shape fabric and crystal texture on marble degradation phenomena: simulations. Environ Earth Sci (submitted)
Siegesmund S (2008) Neue Steine und alte Sorgen-Fassadenplatten aus Naturstein: Sicherheitsrisiken und Sanierungsstrategien. In: H. Venzmer (Hrsg.) 19.Hanseatische Sanierungstage Bauphysik und Bausanierung Heringsdorf 2008, S. 17-27, Beuth Verlag, Berlin

Siegesmund S, Rüdrich J, Weiss T (2004) Marble deterioration. In: Prikryl R (ed) Dimension stone. Taylor and Francis Group, London, pp 211-217

Siegesmund S, Rüdrich J, Koch A (2008a) Marble bowing: comparative studies of three different public building facades. Environ Geol 56:473-494

Siegesmund S, Mosch S, Scheffzük Ch, Nikolayev DI (2008b) The bowing potential of granitic rocks: rock fabrics, thermal properties and residual strain. Environ Geol 55:1437-1448

Strohmeyer D (2003) "Gefügeabhängigkeit technischer Gesteinseigenschaften." Dissertation zur Erlangung des Doktorgrades, Universität Gottingen

Suzuki KO, Kuwahara MT, Hirama K (1995) Material property changes in granitic rock during long term immersion in hot water. Eng Geol 40:29-39

UNE-EN 1936 (1999) Determination of the real and apparent density and the open total porosity. AENOR, Madrid, p 11

Vázquez P (2010) Granitos ornamentales: caracterización, durabilidad y sugerencias de uso. Tesis Doctoral. Universidad de Oviedo

Vollbrecht A, Rust S, Weber K (1991) Development of microcraks in granites during cooling and uplift: examples from the Variscan basement in NE Bavaria, Germany. J Struct Geol 13(7):787-799

Weiss T, Siegesmund S, Fuller ER (2002) Thermal stresses and microcracking in calcite and dolomite marbles via finite element modelling. In: Siegesmund S, Weiss T, Vollbrecht A (eds) Natural stones, weathering phenomena, conservation strategies and case studies, special publications 205. Geological Society, London, pp 89-102

Weiss T, Siegesmund S, Fuller E (2003) Thermal degradation of marbles: indications from finite element modelling. Build Environ 38:1251-1260

Winkler EM (1994) Stone in architecture. Berlin

Winkler EM (1996) Properties of marble as building veneer. Int J Rock Mech Min Sci Geomech Abstr 33(2):215-218

Zeisig A, Siegesmund S, Weiss T (2002) Thermal expansion and its control on the durability of marbles. In: Siegesmund S, Weiss T, Vollbrecht A (eds) Natural stone, weathering phenomena, conservation strategies and case studies. Geol Soc London Spec Pub 205: 65-80 